\title{
The Judicial Review of the Responsibilities of the Company to the Payment of the Money Guarantee the Death of Labor based on Law Number 24 the Year 2011 about BPJS Employment
}

\author{
Trionoeddy S H., M. Hum (Corresponding Author) \\ Magister Ilmu Hukum, Program Pascasarjana \\ Universitas Muhammadiyah Sumatera Utara, Indonesia \\ E-mail: triyonoeddyshmhum@gmail.com
}

Received: April 11, 2017 Accepted: May 29, 2017 Published: May 31, 2017

doi: 10.5296/jsss.v4i2.11060 URL: http://doi.org/10.5296/jsss.v4i2.11060

\begin{abstract}
The implementation of Act No. 242011 is a rule that should be reviewed because many pro-cons who must be responsible for work accidents employees. Here, the author is interested in examining about the judicial review of Corporate Responsibility for the payment of the money guarantee the death of Labor Based on Act No. 24 The year 2011 About BPJS. And here is the author took three formulations of the problem is how the general settings employment social security program in Indonesia, how the role of the law in the BPJS provides protection against the sacrifice guarantee the death of work accidents in Indonesia and law sanctions for companies who are unaware of the responsibility of safety against workers based on Act No. 24 The year 2011 About BPJS. The type of this bachelor theses researches using qualitative research, with wearing the kind of legal research normative and data collection technique use the secondary technique, which consists of the Primary legal materials, secondary, and tertiary preventive measures and data collection method used is a library research method (Library Research). Regarding Accountability and sanctions for companies that have forgetfulness is responsible for workers deaths work accidents has been regulated in the regulation of RI NO. 862013 regarding the administrative sanctions for the company. Now the conclusion is accountability for workers deaths work accidents that should be accountable by the company has not yet to be implemented with good because there are still many companies that are still unaware of the responsibility is while work accidents
\end{abstract}


continue to increase.

Keywords: Accountability, Company, Guarantee death

\section{Introduction}

Basically, the development and development countries to make a country becomes more develop needed qualified human resources and personnel. This case is a critical influence on the success or failure of a country into a more advanced. To get it work, the community must be more productive, and more have a high level of loyalty to the work that was earned. Because, it is a significant impact to make more workers have the knowledge and insights that more.Sometimes workers forced to accept the working relationship with employers, moreover now with the number of labor that is not comparable to the jobs that exist. As a result, affect the workers often oppressed by the entrepreneurs with the reward that is relatively small.

The working relationship is a starting point for the working system that aligns and good in a good company in the or is outside of the land each of labor must serve and work optimally standstill he works to increase the quality of labor. Labor health and safety is a thought and efforts to ensure the integrity and the perfection of labor whether it was seen from the physical and the spiritual. But despite the Constitution guaranteed the right to work and livelihood that worthy, in absolute terms the problem of labor, especially about work accidents, very became the main highlight in entering a world of work, due to there are still many are the victims of workplace accidents that died from workplace accidents.

Safety became the responsibility of the employers, businessmen and even the government also took part in the labor safety affairs. But the awareness of companies in Indonesia to ensure the safety of their work is still very low so that the government should socialize for maximum again will this for employers and require their employers who want to establish the company to give priority to the safety. The Government has an obligation to give the sanction decisively to employers who do not pay attention to the safety of the workers. Although the government and companies have sought safety, death could still occur on workers in running his work. So that the government will also need to protect the workers that accident with the rules to replace the losses of the employees and families of employees. This case is also the right of the workers to become an obligation for the giver of employees to change the loss worthy according to the legislation

\section{Discussion}

The social responsibility of a company is a business commitment to act ethical, to operate legally and contribute to improving the economy at the same time with the improvement of the quality of life of employees and the local community. The most important company obligation as a direct result of a valid labor agreement is paid wages. The other main obligations that according to the existing regulations, placed on employers is to set the work, regulate the workplace, provides information letter and as an additional obligation to hold the book the wages of the book payment of salary, and others. There is also a general obligation of the other agreement is employers are generally required to do or not to do something that in the same situation should be done or not done by a good company. Allowance to workers who do not work because it suffered an accident, benefits sick, old-age benefits and other 
social security is a particularly close relationship with the reward, so in while the decision of antiquity is called with the reward that is suspended.

On the contrary, because social security is not always borne by the employer itself, but sometimes financed together by workers and employers, even very often with state fee, then in modern literature this social security is seen regardless of the wages and stand alone as the income of the workers accepted during able or not able anymore to work. The obligation of the company to set up the work and to set up the workplace that does have a purpose of cultivating the care of health and safety in the work environment. Liability employers who home are the rewards of labor which wages are the size and shape are specified in the working agreement itself and are also regulated by labor laws about minimum wages and the wages of maximum.

In addition to the principal obligation to pay for and the obligation to provide information letter at the request of the workers at the end of the working relationship, required to employers set up the work and set up the workplace. The conditions that must be met in managing the work and set up the workplace is regulated by the rules governing safety and closely monitor the in work. It also has the obligation the company namely: (a) the Company could not practice discrimination, (b) Companies must ensure the health and safety (c) Companies must provide a fair salary, (d) companies cannot be dismissed employees badly mistreated. Labor obligations in general summed up grows in the right employers, as also the worker's rights are summed up in the obligation companies. Working on the other party means on majors work controlled by the direction of the other party and because the charge is most necessary for the worker is doing the work according to the instructions of the employer. The work that must be done by workers is especially the work that has been specified in the working agreement. In addition to the company, labor also has certain obligations that they must meet against bolstered to walk him and program the system with good. Workers are required to do the work which has been promised if the nature and extent of the work are not specified in the agreement or the regulation of the employers, so the customs that will determine.

Besides, there are three general obligations of labor which required met, namely: (a) obligations of obedience; For those who have working ties with companies, one of the implications of its status as an employee is that he must comply with the commands and instructions from his superiors. But the employees do not need and in fact could not follow the commands and instructions that sent him to do something immoral or offenses against the rules apply. (b); confidential obligations obligation to store information that is confidential and therefore a secret that has been obtained by running a profession. Because a worker in a company, can only briefly describe the secret of the company to the other party. So it does not need to be questioned again why employees are required to store the secret of the company because of the base on ethics. (c) Obligations of loyalty ; Employees must support the objectives of the company, because as the employees engage to realize the goals, and therefore he must avoid all things that are against him. In other words, he must avoid things that could harm the interests of the company. Corporate Responsibility is a concept that the company has various forms of responsibility toward all stakeholders significance among consumers, employees, shareholders, community and the environment in all operational 
aspects of the company which includes economic issues, social and environment.

Therefore, corporate responsibility is closely related to the sustainable development, where an organization primarily company, in carrying out its activity must base its decision is not merely based on the impact of the economic aspects, for example the level of profits or dividends, but also must be weighed on the social and environmental impacts that arise from its decision, both for the short term or for a longer period. With the understanding, corporate responsibility toward sustainable development goals with how management affects all stakeholder interests.

Corporate Responsibility refers to all the effort to create the company act in a responsible voluntarily because of the ethical considerations and social. The company in running the business, expected/required to need corporate social responsibility toward stakeholders and external and internal. The responsibility is an important idea that makes the company is no longer confronted with the responsibilities that stand on the single bottom line, namely the value of the company is reflected in the financial condition alone. The awareness will be major responsibility have not only economic and legal obligation to shareholders, but also the obligation to the other parties interested.

The following is a form of corporate responsibility on the workforce: (a) Reward worthy; entrepreneurs who will always pay attention to the welfare of the workforce. Start from the wages of that righteous according to UMR Per, health and safety. (b) Occupational Health and Safety (K3); K3 has primary objectives to promote and develop the process of industrialization, especially in realizing the welfare of the workers. Also, K3 as efforts to prevent and eradicate diseases and accidents are caused by work, maintenance and improving the health and nutrition of labor, maintenance and enhances the efficiency and productivity of labor power man. (c) Minimize the work accidents and refuge; so that workers can be guaranteed health conditions and the highest productivity, then need to balance that benefit from the workload factor, additional burdens as a result of the work environment and the capacity of the work of the workplace health environment so terrible can decrease the degree of health and power also works. So it is critical to note the control efforts to prevent, reduce even pressing the circumstances.

In the case of labor that died, heirs of the workers are entitled to the rights of him who became the responsibility of the company by the applicable law or the rights of which have been arranged in the working agreement, company legislation, or working agreement. This case means that the responsibility of the company in the state of workers who died was dependent upon the regulation or the rights as outlined in this agreement. The benefits of corporate responsibility involve the stakeholders, especially labor. For the company, the benefits of this are to build a positive image of the company in the eyes of the community and the government so that the company can show the forms of social and economic responsibility of the company that implemented by the company in labor work. The interests of labor can be accommodated by the company. Besides, other benefits of the labor can strengthen relationships between employment with companies. This impact to the loyalties of workforce against the company. Because this can lead to a sense of a high level of confidence of labor against the mine concerning comfort, security and calm them in work. To minimize the feeling anxious, complain, and even up to reduce the demo action against the company. 


\section{Ml Macrothink}

Journal of Social Science Studies

ISSN 2329-9150

2017, Vol. 4, No. 2

Also, this benefit also can be felt by the government. The Indonesian government has a partner in running the social vision and mission in the future. The government also has the role of participating in the accommodated community in to meet their needs in the working world, especially the needs of the absolute and primary needs.As has been described in the Law Number 3 The year 1992 about Workers Social Security which is a protection system that is intended to tackle the social and economic risks to the workers directly resulting in diminished or loss of income labor that suffered work accidents. Based on this rule and the company are required to attend the program employees social security that occurred with the way charged energy it operates in the body of the organizer of the Social Security (BPJS Employment). Broad principles of his nature of work accidents that embraced by Law Number 3 The year 1992 that each of labor entitled to workers social security. This case applies when the accident work. Work accidents here is an accident occurs that is directly related to the workplace accidents, including one disease that arises because of working relationship. So did the accident happens to employment in the journey to go and return from the house toward the workplace whether it passes through the normal way of he passed through or over the other way.

As mentioned in Article 1 paragraph (4) Act OnThe BPJS reads: "Participants is everyone including the foreigners who work most short period of 6 months in Indonesia, which has pay dues". While the participation of the employees in the BPJS has been arranged in Article 15 paragraph (1) BPJS Laws that reads:"employers gradually must register themselves and their workers as participants to the BPJS following the social security program that followed." So, in agreement with the terms of the above strengthen the position of labor as a company employee is required to be included in the BPJS Employment by the company as employees. These conditions assured return in Article 3 paragraph (1) Regulations Of The Government Of The Republic Of Indonesia N0. 862013 about procedures for the administrative sanctions to employers in addition to state officials and everyone, besides employers, workers and beneficiaries of the dues in the event of social security which reads :"employers besides agents of the state required: (a) Register themselves and their employees as participants to the BPJS gradually in accordance with the social security program following; and (b) Provide data itself and the following employees family members to complete BPJS and accurate" The penalty for employers who violate the obligation to register the employees as participants BPJS is the administrative sanctions. This administration Sanski as (a) reproof is written; (done by the BPJS), (b) a penalty of 1 Billion Rupiah/prison in 8 years in prison; and (done by the BPJS), and (c) did not get the specific public services. (done by government or local government at the request of the BPJS).

The sanctions do not get public services that particular known to employees in addition to state officials include: (a) Permissions related businesses; (b) the required permissions in the following bid on projects; (c) permission to employ foreign labor; (d) Permission services provider company workers; (e) building permit (IMB).

\section{Conclusions}

The history of the formation of employment BPJS has the origin of the term. Starting from the formation of Act No.33/1947 jo Act No.2/1951 about work accidents, and the formation of JAMSOSTEK based on Act No.3 Year 1992 until 2011 JAMSOSTEK are transformed into 
labor BPJS based on Act No.24 2011 which organized labor social security program covers, warranty work accidents (JKK), Guarantee death (JK), Guarantee the Elders (JHT), with the addition of the Pension Guarantee (JP) start date of 1 July 2015.

Labor BPJS give the form of protection to the victims of the death of labor in the form of lump sum and the scholarship in the form of money to the beneficiary labor that died. Now the role of the act in the implementation of this Employment BPJS in providing protection against workers died from workplace accidents to manage and monitor everything that happens in the scope of this employment social security so that the lack of misconducts happened. It is including gives sanction to companies that negligent in providing welfare to the workforce. The company and workers have the obligation of each for the operation of work well and smoothly. With the existence of the obligation the company had any sense of responsibility for salvation and calm workers, the responsibility is in the form of wages that worthy, health and safety register labor work to the BPJS Employment in order to guarantee the safety of labor in doing the work activities so that the workers can work with high loyalty. Now the sanction was given to companies that negligently responsible for the workforce namely reproof written, fines, and not get certain public services. That is very good when held an instruction conducted by the DISNAKER about the rights and obligations of labor to the work party and his family in order to know the workers labor regulations that protect the rights and interests and the welfare of the employees and his family, so that there is no longer the workers do not know the rules that protect their interests.

The position of the labor is the position that is not so beneficial for the work under the direction of others who function as employees where the energy used to produce a production of goods or services with the income budget enthusiasts to live his family. So we as human beings are religious and high selfish and immoral, let us build the life that respects one another especially the employers must comply with the workers as the same man in rank before the Lord and do not placed on the lower status and do not always do things at the expense of the workers for the benefit of themselves as well as the advantages of the company. In this occasion the authors suggest the party DISNAKER so that actually held a check to the companies that employ workers as workers in a production, whether workers are already registered to labor social insurance (BPJS) or not because in the current era are still many companies that did not register its employees to become a member of the BPJS Employment

\section{References}

Alhamda, S., \& Sriani, Y. (2015). Buku Ajar Ilmu Kesehatan Masyarakat, Jakarta.

Asyhadie, Z. (2007). Hukum Kerja (hukum Ketenagakerjaan bidang hubungan kerja). Jakarta: Raja Grafindo Persada.

Berata, I., \& Komang, O. (2012). Panduan Praktis HRD \&GA, Raih asa sukses, Penebar Swadaya grup, Bogor.

Bahransyaf, D. (2004). Pengembangan ketahanan sosial masyarakat melalui sistem jaminan sosial berbasis masyarakat. Departemen Sosial RI, Badan Pelatihan dan Pengembangan Sosial, Pusat Pengembangan Ketahanan Sosial Masyarakat.

Husni, L. (2007). Pengantar Hukum Ketenagakerjaan Indonesia Edisi Revisi, Divisi Buku 


\section{Macrothink}

Perguruan Tinggi PT Raja Grafindo Persada, Jakarta.

Ihromi, T. O. (2000). Antropologi dan Hukum. Yayasan Obor Indonesia.

Kartasapoetra, G., \& Widianingsih. R. G. (1992). Pokok-Pokok Hukum Perburuhan, Armico, Bandung.

Maimun. (2007). Hukum Ketenagakerjaan Suatu Pengantar, PT. Pradnya Paramita, Jakarta.

Muslim, N. (2006). Suatu Tinjauan Mengenai Pembayaran Uang Jaminan Kematian Tenaga Kerja, Skripsi, Medan.

Nuryanti, A. E. (2006). Perlindungan Hukum Terhadap Pekerja Harian Lepas Di UD Berkah Sedulur Desa Tanjungsari Kecamatan Rembang Kabupaten Rembang (Doctoral dissertation, Universitas Negeri Semarang).

Simanjuntak, J. P. (1998). Tenaga Kerja Indonesia, Balai Pustaka, Jakarta.

Soepomo, I. (1992). Hukum Perburuhan Bidang Hubungan Kerja, Penerbit Djambatan, Jakarta.

Suma'mur, P. K. (1981). Keselamatan kerja dan pencegahan kecelakaan. Gunung Agung.

Samawi, A. (2008). Pendidikan Hak Asasi Manusia, Diroktorat Jenderal Pendidikan TinggiDepartemen Pendidikan nasional , Jakarta.

Senduk, S. (1999). Merancang Program Pensiun, PT Elex Media Komputindo, Jakarta. International Labour Organization (1985), Majalah Astek.

ST, M. N., \& Hum, M. (2009). Tanya Jawab Seputar Hak-hak Tenaga Kerja Kontrak. VisiMedia.

Wikipedia Bahasa Indonesia ,Ensiklopedia Bebas, http:/ id.Wikipedia Tenaga_kerja, 14November 2015 , 20.00 WIB.

Shvoong, "Pengertian Tanggung Jawab", http://id.shvoong.com/books/1773765-tanggung-jawab/, diakses tgl 4 Januari 2016, pukul 12.10 WIB.

\section{Copyright Disclaimer}

Copyright for this article is retained by the author(s), with first publication rights granted to the journal.

This is an open-access article distributed under the terms and conditions of the Creative Commons Attribution license (http://creativecommons.org/licenses/by/3.0/). 